\title{
Preliminary Study: Development of Algodoo-based Newtonian Teaching Materials to Improve Student's Conceptual Understanding with Peer Instruction Method
}

\author{
Muhammad Aswin Rangkuti ${ }^{1}$, Winsyahputra Ritonga ${ }^{2}$, Ida Wahyuni ${ }^{3}$, Septian Prawijaya ${ }^{4}$ \\ \{aswin_ray,winsyahputra ${ }^{1}$,idawahyuni@unimed.com ${ }^{2}$,wijaya@ unimed.ac.id ${ }^{3}$ \} \\ Department of Physics, Universitas Negeri Medan, Jalan Willem Iskandar Pasar V, Medan Estate \\ 20221, Indonesia ${ }^{1,2,3,4}$
}

\begin{abstract}
Some of the worlds physics communities have observed that student learning outcomes in introductory physics courses are weak and ineffective. To overcome this, one of the efforts to complete it is the development of effective teaching materials. Excellent teaching materials will help students in solving problems in learning including deep conceptual understanding. Many misconceptions occur for students who have completed introductory physics courses. Whereas in the introductory physics courses there are many major branches of physics. Conceptual understanding is a part that cannot be missed in the whole of physics learning. Weak understanding of the concept will affect the completion of mathematical physics questions. Sometimes students can solve a physics problem that is mathematical but does not understand the concepts contained in it. One method of solving physical misconceptions in students is to use peer learning methods whose activities are arranged in instructional materials developed based on Algodoo. This method is expected to reduce the misconceptions that occur for students who take Introductory Physics courses during their first year of college.
\end{abstract}

Keywords: Teaching Material, Conceptual Understanding, Algodoo

\section{Introduction}

Physics is the study of matter, energy, and interactions contained in it. The knowledge contained in physics plays an essential role in the progress of humanity. Physics covers the realm of science that is widely used by chemists, computer engineers, and scientists, as well as other practitioners of physical and biomedical sciences.

Physics began to be introduced to students ranging from elementary to high school. When these students study with science majors, they are likely to return to studying physics at the beginning of the semester. There are several mentions of introductory physics courses at several universities in Indonesia such as Basic Physics, General Physics, and Physics Introductory. At Universitas Negeri Medan itself since the implementation of the KKNI-based curriculum, introductory physics courses in the first year of lectures at FMIPA are "Basics of Mechanics and Heat" and "Basics of Wave, Electricity, and Magnets."

Conceptual understanding of physics must be accepted by students well in college because the physical sciences always relate to one another. Therefore, a good conceptual understanding 
will prepare students better in starting the next lesson. Conceptual errors in students will have an impact on higher learning stages (Daud et al. 2018; Widarti, Permanasari \&Mukyani, 2017).

To help students' understanding in building an excellent conceptual understanding, one of them is the lecturer must apply media that suits the needs of students. Virtual media in physics learning can help students visualize physical phenomena interactively (Wibowo et al., 2016). Algodoo is one of the virtual media offered in physics learning, especially in introductory physics courses (Euler \& Gregorcic, 2017). The use of Algodoo is expected to help students learn actively and creatively.

In this preliminary study, the author offers the development of Algodoo-based Newtonian teaching materials which later can be used by students in introductory physics courses. Also, the author also offers the use of peer teaching methods in solving specific problems in textbooks that will be created. The use of peer teaching methods will help students to confirm the knowledge that is in themselves (Fagen, Crouch \& Mazur, 2002).

\section{Method}

\subsection{Type of Research}

This research includes development research using the Thiagarajan teaching material development model. The teaching material developed in this study is Newtonian based Algodoo material. 


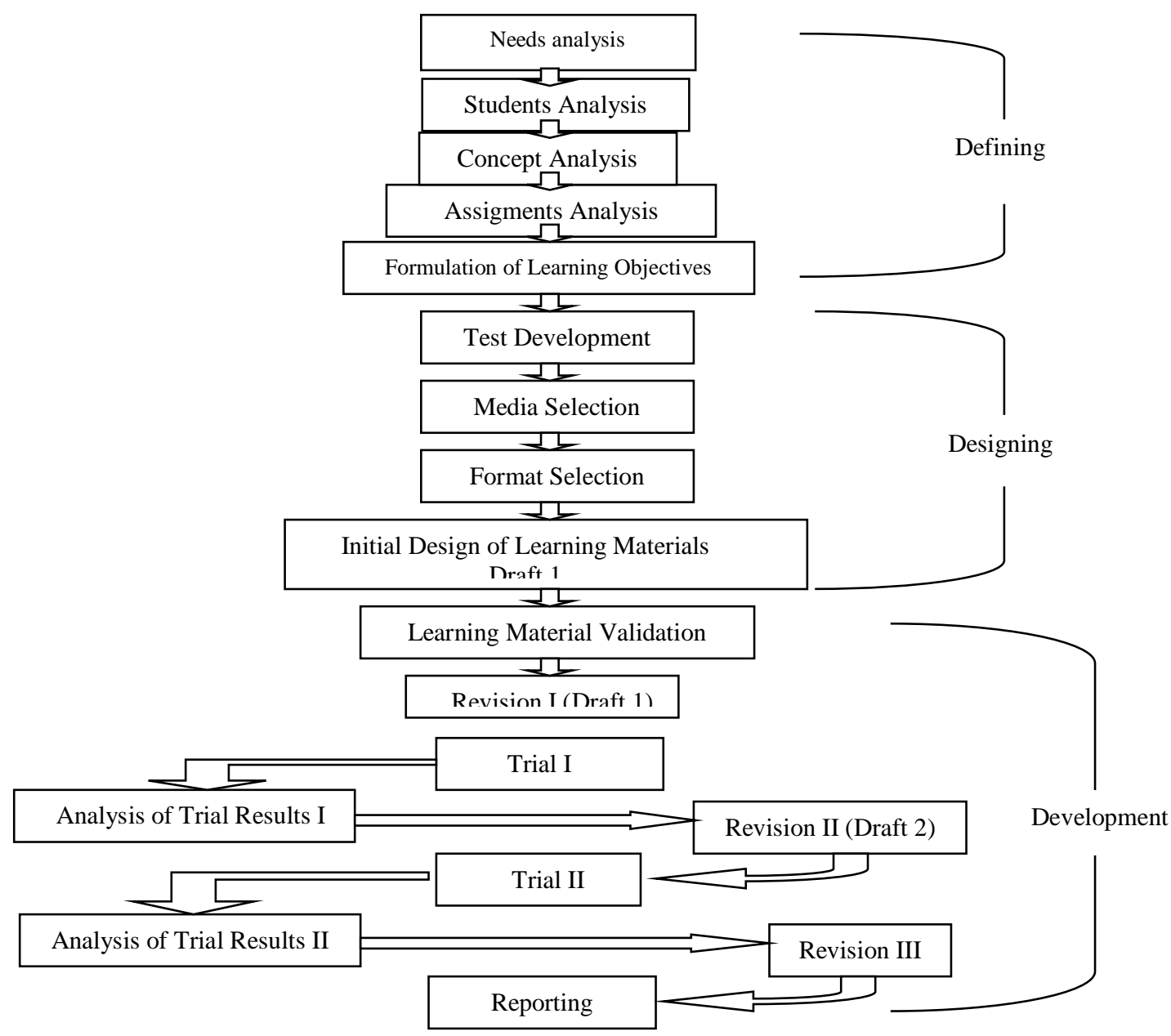

Fig .1. Thiagarajan 3D Learning Material Development Mode

\subsection{Development of Teaching Materials}

The development model used in this study is a learning material development model proposed by Thiagarajan (Thiagarajan, 1974). The Thiagarajan model consists of four stages (four-D models): define; design; development; dissemination. However, the stage undertaken in this study is only up to the development stage, because teaching materials will be used in the university themselves. 


\subsection{Data Collection and Instrument Techniques}

Data collection techniques by questionnaire. There are four types of questionnaires that are used to capture information and data needed in the development of textbooks, which are prepared based on the needs and suitability of the information for students in Basic Mechanics and Heat. After the preparation of teaching materials is complete, the Algodoo-based Newtonian teaching materials will be applied to students to see a Newtonian conceptual understanding of students.

\subsection{Research Procedure}

This research activity is divided into three stages, namely: (1) Planning; (2) Implementation; and (3) Data analysis.

\subsubsection{Planning}

Collect information from first semester students who take Introductory of Physics course on 1) Material to be developed;2) Character of students; 3) Tasks and learning objectives to be developed, and 4) Preparing teaching materials based on information that has been received.

\subsubsection{Implementation}

The steps taken in the implementation phase are as follows:

1. Conducting a feasibility test on the product that has been compiled to material and learning design experts, by giving an assessment sheets

2. Conduct revisions based on criticism and suggestions provided by a team of material and learning experts.

3. Conducting trials on students who take Introductory of Physics courses to analyze conceptual understanding using the teaching material.

\subsubsection{Data Analysis}

Data analysis in this study is descriptive, which explains a symptom-problem, or the situation as it is and not tests the hypothesis. The data obtained in this study are qualitative data obtained from questionnaire answers filled by students and expert teams.

\section{Discussion}

In this preliminary study, the author offers an alternative method in teaching the introductory of physics to students in the Faculty of Mathematics and Natural Sciences, Universitas Negeri Medan. Newtonian teaching materials developed will apply Algodoo as an activity that can be used by students to build a better conceptual understanding of physics. Algodoo-based teaching materials will assist students in obtaining self-assessment. This strategy will help students develop instructional knowledge (Mason \& Singh, 2016). 
The peer teaching method will also be used to solve problems using Algodoo. This method will develop students' conceptual abilities and attitudes towards a better direction, especially for students in universities (Zang, Ding \& Mazur, 2017; Martin, 2016). This method will give students the opportunity to express their initial ideas and then confirm them with their peers. Some researchers have shown positive results in the use of peer teaching methods in universities in various applied sciences (Teixeira et al. 2015; Graziano, 2017; Sayer, Marshman \& Singh, 2016).

The use of Algodoo will help students improve their creativity by visualizing physical events in the Algodoo system (Gregorcic \& Bodin, 2017). This strategy will undoubtedly run more effectively by learning peer teaching methods with Algodoo-based teaching materials. The author hopes that students can discuss with their peers to answer the problems in Newtonian material based on Algodoo so that the conceptual knowledge of students will be built during the discussion process.

\section{Conclusions}

Based on the results of the discussion, it can be projected that Algodoo-based teaching materials combined with peer teaching methods will make the learning process in the introductory physics courses run more effectively. This study was made as a preliminary study to study the potential use of Algodoo applications in preliminary Physics teaching materials at the Faculty of Mathematics and Natural Sciences, Universitas Negeri Medan.

\section{References}

[1]Daud, N.S.N., Karim, M.M.A., Hassan, S.W.N.W. and Rahman, N.A., 2015. Misconception and Difficulties in Introductory Physics Among High School and University Students: An Overview in Mechanics (34-47). EDUCATUM Journal of Science, Mathematics and Technology (EJSMT), 2(1), pp.34-47.

[2]Euler, E. and Gregorcic, B., 2017. Physics Students' Use of Algodoo in Modeling. In American Association of Physics Teachers (AAPT) Summer Meeting, Cincinnati.

[3]Fagen, A.P., Crouch, C.H. and Mazur, E., 2002. Peer instruction: Results from a range of classrooms. The physics teacher, 40(4), pp.206-209.

[4]Graziano, K.J., 2017. Peer teaching in a flipped teacher education classroom. TechTrends, 61(2), pp.121-129.

[5]Gregorcic, B. and Bodin, M., 2017. Algodoo: A tool for encouraging creativity in physics teaching and learning. The Physics Teacher, 55(1), pp.25-28.

[6]Mason, A. and Singh, C., 2016. Using categorization of problems as an instructional tool to help introductory students learn physics. Physics Education, 51(2), p.025009.

[7]Sayer, R., Marshman, E. and Singh, C., 2016. Case study evaluating Just-In-Time Teaching and Peer Instruction using clickers in a quantum mechanics course. Physical Review Physics Education Research, 12(2), p.020133.

[8]Stigmar, M., 2016. Peer-to-peer teaching in higher education: A critical literature review. Mentoring \& Tutoring: Partnership in Learning, 24(2), pp.124-136.

[9]Teixeira, K.C., Silva, T.E., Mota, J.C., Barroso, N.C. and Teixeira, E.V., 2015, October. Peer instruction methodology for linear algebra subject: a case study in an engineering course. In Frontiers in Education Conference (FIE), 2015 IEEE (pp. 1-7). IEEE. 
[10]Thiagarajan, S. Semmel, D.S. Semmel, M. 1974. Instructional Development for Training Teachers of Exceptional Children. A sourse Book. Blomington: Central for Innovation on Teaching The Handicapped.

[11]Wibowo, F.C., Suhandi, A., Rusdiana, D., Darman, D.R., Ruhiat, Y., Denny, Y.R. and Fatah, A., 2016, August. Microscopic Virtual Media (MVM) in Physics Learning: Case Study on Students Understanding of Heat Transfer. In Journal of Physics: Conference Series (Vol. 739, No. 1, p. 012044). IOP Publishing.

[12]Widarti, H.R., Permanasari, A. and Mulyani, S., 2017. Undergraduate Students' misconception On Acid-Base And Argentometric Titrations: A Challenge To Implement Multiple Representation Learning Model With Cognitive Dissonance Strategy. International Journal of Education, 9(2), pp.105-112. 